\title{
Notes on the Presence of the Elements of Theology in Ficino's Commentary on the Philebus
}

\author{
Sokrates-Athanasios Kiosoglou \\ Katholieke Universiteit Leuven
}

\section{$1 \quad$ Introduction*}

This short essay is intended to partly discuss how Proclus' Elements of Theology radically shaped Marsilio Ficino's Commentary on the Philebus. Without entering into the debate about the latter's significant influence over Ficino's 'original' philosophical works, ${ }^{1}$ it shall present certain corresponding passages between the Elements of Theology and the Commentary on the Philebus. Moreover, apart from the effort to unearth philological or doctrinal affinities between these texts, there is an ongoing scholarly discussion, on which I shall not focus here, about Ficino's translation of the Elements of Theology. ${ }^{2}$ Although it does not aspire to be exhaustive, this essay serves, however, three objectives: first, it starts with certain introductory remarks that bring out Ficino's reception of the Philebus and the context of his preoccupation with this late platonic dialogue; second, it proceeds with a comparison of selected passages of the Elements of Theology and the Commentary on the Philebus on a purely textual and philological basis, hence Moerbeke's Latin translation was preferred to Proclus' Greek text; finally, it attempts to concisely offer some suggestions concerning the philosophical significance of some of the affinities and discrepancies between the excerpts under comparison.

* This text has been written within the framework of the project Axiomatic-deductive method and more geometrico presentation in Proclus, which is carried out by Jan Opsomer and Pieter d'Hoine and funded by KU Leuven, Internal Research Funds. I wish to express my most sincere thanks to Professor Dragos Calma for his unsurpassed support and guidance, to my $\mathrm{PhD}$ supervisors, Pieter d'Hoine and Jan Opsomer, for their trust and encouragement, as well as to deeply thank for their incessant help and valuable feedback Professors George Steiris, Thomas Leinkauf, Jacomien Prins, Denis Robichaud, Valery Rees, Paul Kalligas, Voula Tsouna, Ineke Sluiter and Bert van den Berg.

1 See Allen's crucial remarks in Marsilio Ficino, The Philebus Commentary, p. 2, 11-12.

2 Robichaud 2016, p. 50, 54. 
Except for translating and successively commenting on the Philebus (in 14661467 according to Steel $^{3}$ or in $1469^{4}$ according to Allen, and also in 1491 and 1492 for its second and third version respectively), Ficino also lectured on it publicly, these lectures providing the basis for the Commentary on the Phile$b u s,{ }^{5}$ serving as an introduction to Platonism ${ }^{6}$ and even aiming to uplift the moral and political status of his fellow Florentines. The fact that Ficino resorts to the Philebus (a radically unpolitical dialogue) for 'political' purposes allows us to better conceive of the intellectual and philosophical challenges he faced, since it sheds further light on his endorsement of a 'medical model' for philosophy and provides us with a fuller picture of how the enterprise of reviving Platonism came to be the historical role and task Ficino invented for himself. ${ }^{7}$ However, all this vivid interest in an unquestionably abstruse dialogue is not understandable by itself, but if one considers the continuous commentary tradition preceding it. Contrary to what is currently the case, since the Philebus "if it is studied at all, it is reserved for the arcane discussions of graduate seminars

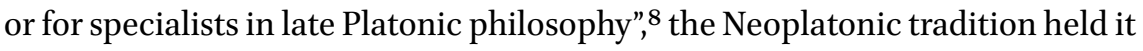
in high esteem. One may discern here two fundamental aspects.

a) Given that Aristotle's Nicomachean Ethics enjoyed wide acceptance and dominated the philosophical milieu, in his Commentary on the Philebus, Ficino made good use of Damascius' In Philebum ${ }^{9}$ and explicitly argued for a pleasure in ipso cognitionis actu, ${ }^{10}$ whereby he enriched Plato's replenishment model ${ }^{11}$ and gave a thorough account of the way in which the reversion towards the One (that is, the Good and God), which satisfies our God-oriented appetitus, can be fully rewarding and pleasurable.

b) While in the Republic Plato hesitantly offered his readers a rather reserved account of the Good and Socrates restricted himself to certain cryptic and insufficiently illuminating formulations, the Philebus was thought by Neoplatonism as much more promising in this respect. ${ }^{12}$ The three 'fea-

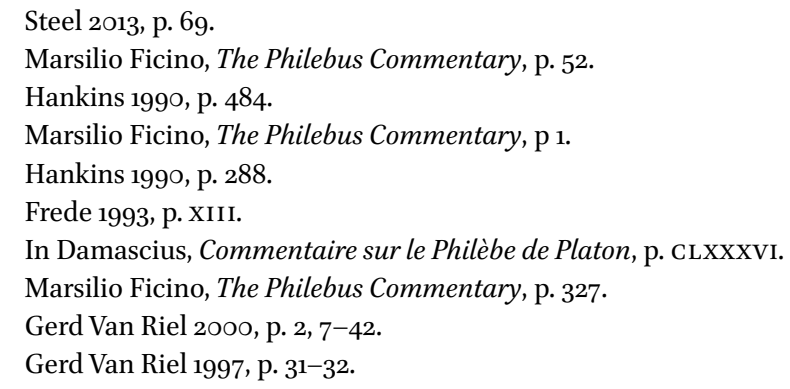


tures' of the Good, introduced in $20 \mathrm{~d}$ (translated by Ficino as sufficiens, expetendeum, perfectum) along with the unity of beauty, proportion and truth (65a) that secures the stability of the final mixture of the good life are all interpreted in connection with the Christian God. ${ }^{13}$ Ficino was thus in position to reconstruct a robust platonic theory of the Good, much more convincing and detailed than that in the Republic, ${ }^{14}$ and then subtly Christianize it in order to publicly argue for it in Florence. On top of that, he saw a decisive complementarity between the Philebus and the Parmenides, for the identification of the human good in the former ${ }^{15}$ depends, according to him, on the specification of the One or the Absolute Good in the latter. ${ }^{16}$

Elements of Theology and the Commentary on the Philebus: Existing Evidence and New Suggestions

In one of his impressive contributions, Carlos Steel masterfully established that in articulating this metaphysical system, Ficino systematically draws from Proclus' Elements of Theology (and from his Parmenides Commentary, to which I shall not focus here). The evidence he adduces is overwhelming and proves that Ficino literally uses numerous and lengthy passages from the Elements of Theo$\operatorname{logy}{ }^{17}$ The following annexes include some passages that seem to have been equally inspired by the Elements of Theology. That their degree of correspondence with the latter significantly varies (from passages taken almost literally to freely adapted or slightly modified ones) shall not make us underestimate the extent to which the most principal philosophical starting points of the Commentary on the Philebus are of a Proclian origin.

13 Marsilio Ficino, The Philebus Commentary, p. 283-297, l. 355-369.

14 The idea that the Philebus adduces further arguments concerning the nature of the Good and thereby continues the relevant discussion of the Republic may also explain why Plato reintroduces Socrates in the Philebus; it seems more plausible that Socrates is back in order

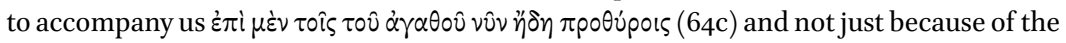
dialogue's moral character. Cf. Delcomminette 2006, p. 12-13.

15 Robichaud 2018, p. 170.

16 Marsilio Ficino, The Philebus Commentary, ch. vi (p. 113), ch. I of the second book (p. 387389 ).

17 Steel 2013, p. 73-74, 95-97. Explicit mention is made of prop. 1-4, 5, 20 for chapter IV, prop. 13 for chapter $\mathrm{V}$ and prop. 12 for chapters $\mathrm{V}$ and $\mathrm{XxX}$. 
Annexes

I)

Proclus, Elements of Theology (ed. H. Boese)

8o. Omne corpus pati secundum se natum est, omne autem incorporeum agere, hoc quidem operosum ens secundum se, hoc autem passionale; patitur autem et incorporeum propter communionem ad corpus, ut possunt agere et corpora propter incorporeorum coexistentiam.

Corpus quidem enim divisibile est solum et hac passibile, omniquaque ens partibile et omniquaque in infinitum. Incorporeum autem, simplex ens, impassibile est. Neque dividi potest quod impartibile neque alterari quod non compositum. Aut igitur nihil erit activum aut incorporeum, siquidem corpus secundum quod corpus non agit, ad dividi solum et pati expositum. Quoniam et omne agens potentiam habet activam, quare non secundum quod corpus aget, sed secundum potentiam agendi in ipso; inefficax autem et impotens corpus secundum se: participatione ergo potentie aget quando agit. Quin immo et incorporea passionibus participant in corporibus facta, condivisa corporibus et assumentia partibilem illorum naturam, impartibilia existentia secundum sui ipsorum substantiam.

43. Omne quod ad se ipsum conversivum est authypostatum est.
Marsilio Ficino, Commentary on the Philebus (ed. Allen)

IV, p. 101. Id totum sic ab initio confirmatur. Cum corpus ex materia constet et quantitatem ratione materiae solum capiat, et ratione quantitatis solum dividatur, sequitur ut per haec pati possit non agere. Siquidem ergo agere videntur corpora, per aliud agunt, forte per qualitatem quae ex se est incorporea, cum plurimae sint eodem in corpore qualitates. Sed neque qualitas est per se principium actionis; quod enim non est per se, per se non agit.

Eundum igitur est ad incorporale aliquid quod per se subsistat neque cum corpore sit divisum, talisque erit anima, quae quia ad se convertitur per se subsistit. Ab ea 
(cont.)

Proclus, Elements of Theology (ed.

H. Boese)

186. Omnis anima est incorporea substantia et separabilis a corpore.

(...) Anima ergo neque corporea est substantia neque a corpore inseparabilis. 191. Omnis anima participabilis substantiam quidem eternalem habet, operationem autem secundum tempus. (...) Relinquitur ergo sic quidem eternalem esse animam omnem, sic autem tempore participantem (...) Omnis ergo anima substantiam quidem eternalem habet, operationem autem secundum tempus.

199. Omnis anima mundana periodis utitur proprie vite et restitutionibus. Si enim a tempore mensuratur et transitive operatur et est hic proprius motus, omne autem quod movetur et tempore mensuratur, perpetuum ens, utitur periodis et periodice revolvitur et restituitur ab eisdem ad eadem, palam quod et omnis anima mundana, motum habems et operans secundum tempus, periodos motuum habebit et restitutiones; (...)

\section{Marsilio Ficino, Commentary on the Philebus (ed. Allen)}

inerit vis agendi corporibus, ergo et vis movendi.

Omnis ergo actus et motus corporum est ab anima, quae essentia incorporalis est, unita corpori non commixta, coniuncta non dispersa. Supra quam est et mens, et essentia incorporalis et a corpore penitus separata. Ideo nihil habet commune cum corpore. Illa stat essentia et operatione; corpus utroque fluit; anima essentia stat, operatione fluit. Illa omnino in aeternitate; corpus in tempore; anima in utroque. Illa movet non movetur; materia movetur non movet; corpus movet ab alio motum; anima movet a se mota. Ergo et mens et materia sunt extrema; media vero corpus et anima. Hoc ad materiam declinat magis; anima magis ad mentem. Cum dicimus animam se ipsa moveri, absolute non transitive verbum illud proferimus, ut cum stare mentem, lucere solem, calere ignem. Non enim pars animae movet pars movetur, sed tota ex se ipsa movetur, id est, discurrit, transigit per temporum intervalla nutritionis augmenti generationis opera, rationis et cogitationis discursiones. Agit mens sed cum aeternitate; agit anima sed cum tempore. Quid motus animae? Actio cum tempore, et quia prima actio cum tempore est in anima, ideo primus motus in anima et est in ea ratione sui in quantum iam a statu mentis degenerat. 
Ficino's digression (id totum ... mentis degenerat) interrupts the direct quotation of prop. 20 of the Elements of Theology (on p. 99 of the edition). ${ }^{18}$ Here, as we can see, he implements another strategy, gathering and unifying material and insights from scattered Proclian passages in the Elements of Theology. Thus, he restates the successive ontological levels explaining how passivity, matter, corporeality, divisibility and quantity impede action. Though his exposition is compatible with the Elements of Theology, we should note Ficino's high sensitivity and accuracy when describing the connection of the incorporeal soul with the body. So as not to jeopardize the former's superiority, he cautiously avoids Proclus' risky formulation, according to which an incorporeal being can assume partibilem naturam (prop. 80) but also remain impartibile secundum sui substantiam. From a doctrinal point of view, his argument is much more safeguarded and moderate: the soul's essence is not threatened as long as the soul is not mixed with or dispersed through the body. In fact, it runs counter

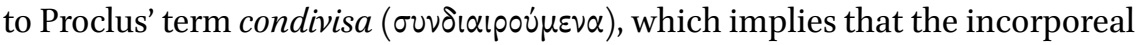
and the corporeal are unified and form a certain kind of 'mixture'. Ficino argues here for a more clear-cut distinction and his very emphasis on the fact that the soul is non commixta with and non dispersa through the body reveals his alertness to properly modify and even reject Proclus' formulations.

II)

8. (...) Quod enim appetit aliquid indigens est eo quod appetit et alterum ab appetibili (...)

9. (...) Si enim omnia entia bonum appetunt secundum naturam, et hoc quidem se ipso exhibitiuum est eius quod bene, hoc autem indigens alio, hoc quidem presentem habet boni causam, hoc autem seorsum existentem, quanto igitur propinquius hoc largienti appetibile, tanto melius utique erit eo quod est indigens separata causa et aliunde suscipiente perfectionem existentie aut operationis.
II, p. 83. Appetitus enim naturalis est necessaria naturae inclinatio ab indigentia quadam adnitens ad plenitudinem. Plenitudo ac finis ultimus idem (...) [p. 85] Adde quod appetitio finis cuiusdam in rebus aut casu est aut usu aut natura (...) Ergo natura; etenim quod inest omnibus et semper a specie est atque natura, ergo ab eo quod est naturae et speciei principium, id est Deus. (...) Ergo [appetitus] ultimum consequitur finem. Non enim frustra praecipit et movet rex sapiens atque bonus, Deus autem per appetitum

18 Steel 2013, p. 95-97. He continues the quotation of prop. 20 on p. 103 until the end of the chapter. 
35. (...) Si autem maneat quidem et procedat, non convertatur autem, quomodo qui secundum naturam appetitus uniuscuiusque ad id quod bene et ad bonum et que ad generans extensio?

134. (...) Et enim ad que intellectuale idioma (vel proprietas) non procedit, ad hec preattingit quod divinum. Et enim non intelligentia provideri volunt et boni alicuius sortiri; hoc autem quia intellectum quidem non omnia appetunt neque quibus participare possibile, bonum autem omnia appetunt et festinant sortiri.

31. Omne procedens ab aliquo secundum essentiam convertitur ad illud a quo procedit.

Si enim proveniat quidem, non convertatur autem ad causam processus huius, non utique appetet causam; omne enim appetens conversum est ad appetibile. At vero omne appetit bonum, et illius ordo per proximam causam singulis; appetunt ergo et suam causam singula. $\mathrm{Per}$ quod enim esse unicuique, per hoc et ipsum bene; per quod autem ipsum bene, ad hoc appetitus primo; ad quod autem primo appetitus, ad hoc conversio. concitat omnia. [XXXI, p. 311] Sic voluntas necessario vult bonum agendi principium instinctu superiori. Trahit enim ad se omnia principium rerum; id autem bonum est. Necessario igitur omnia bonum appetunt.

XXXIII, p. 333. Quia omnia bonum appetunt, mentem vero non omnia. Neque enim assequi mentem et sapientiam omnia possunt. Ideo multa eam frustra appeterent. Et ea quae mente carent non omnia mentem adipisci [p. 335] student. Quae vero mentem habent nondum cessant, sed adhuc bonum quaerunt (...) Primo sic omnia appetendo convertuntur ad bonum, non ad mentem omnia (...) Secundo sic appetitus hominum naturalis omnis et semper ad bonum, non omnis et semper ad mentem; pluris ergo facit bonum quam mentem.

XXX, p. 295. Deinde ratione sic, quia convertit [bonum] in se statim nascentium appetitus. Unumquodque enim bene esse desiderat. Bene esse habet unde et esse. Ad causam ergo convertitur. Etenim suo in esse servari quodcumque appetit. Conservat esse quod esse dat. (...) Eiusdem igitur conservare est, cuius et generare. Effectus igitur causam appetit conservantem. Ipsum ergo bonum, cum sit omnium causa, est omnibus expetendum. 
"From God to God"-here is how one could summarize the philosophical core of the above passages. Indeed, the appetitus, which impels us to turn back to our cause and thus finally gain felicity and pleasure, is described by Ficino as totally manipulated by God, that is, the principle of nature. 19 'Preprogrammed', as it were, this reversion shall culminate in our possession of Him, which signifies the accomplishment of a circular movement on our part as well as three interwoven kinds of perfection: our ontological perfection, for we now 'possess' or are identified with the highest possible ontological level; our ethical perfection, for it would be inconsistent to 'possess' the absolute Good without being in an ethically equally good state; our epistemological perfection, since God or the absolute Good is the highest possible object of cognition, the limit, as it were, of what we may aspire to know. The above excerpts could also be taken to constitute a brief summary of the whole Marsilio Ficino's Commentary on the Philebus in that they include all its crucial conceptual tools and anticipate Ficino's conceptualization of felicity and, by extension, of pleasure. He suggests a worldview, wherein felicity is somehow 'obligatory' and 'imposed' by our very nature, since the latter represents and executes a divine plan that excludes no one. Additionally, one can easily discern how skillfully Ficino blends ethics and metaphysics. Since "natura" is informed by God's will, the modern distinction between a normatively neutral and merely descriptive realm that belongs to nature and another that includes moral and value considerations is still untenable. The Commentary on the Philebus exemplifies the idea that the way things "are" is already instilled with the seed of how they "ought to be". In this respect, the attainment of felicity is dependent on our eagerness to facilitate the deployment of our nature.

III)

21. (...) Quod enim in omni multitudine idem non ab uno eorum que in multitudine processum habet. Quod enim ab uno solo multorum non est commune omnium, sed solius proprietatis illius singulare. (...) Est ergo unitas una ante multitudinem secundum unum-
IV, p. 95. Omnia corpora ad unum mundi corpus; omnes naturae ad naturam unam; omnes animae ad unam animam; omnes mentes ad unam mentem. Bonum vero et unum unumquodque istorum est, ergo omnia bona et una ad unum bonum, sicut numeri

19 Marsilio Ficino, The Philebus Commentary, p. 85. 
quemque ordinem, unam rationem et connexionem exhibens hiis que in ipso ordinantur ad invicem et ad totum. (...)

Ex hiis itaque manifestum, quod nature corporis inest unum et multitudo, et una natura multas habet copulatas, et multe nature ex una sunt totius natura; et ordini animarum adest ordiri ex una anima prima et in multitudinem animarum devenire et multitudinem in unam reducere; et intellectuali essentie monadem esse intellectualem et intellectuum multitudo ex uno intellectu procedens et in illam conversa; et uni ei quod ante omnia multitudinem unitatum, et unitatibus eam que ad unum extensionem. omnes ad unitatem. Unum ergo omnium est principium.

Omnis enim ordo quia in se habet unionem in quantum singula eiusdem sunt ordinis ab uno est supra ordinem. Nam unio ordinis non ab uno quodam ordinis est, esset enim illius proprium neque omnibus conveniret. Ergo ab uno supra ordinem quod est primo tale, ideo [p. 97] nihil aliud est quam tale, ut bonorum principium sit solum bonum;

IV)

143. Omnia deteriora presentia deorum subsistunt; et si idoneum sit participans, omne quidem quod alienum a divino lumine fit, illustratur autem omne subito a diis.

Semper quidem enim divina magis comprehensiva et potentiora sunt procedentibus ab ipsis, participantium autem idoneitas illustrationis divini luminis causa fit; obscurat enim illam sua imbecillitate. Illa autem obscurata aliud aliquid videtur preeminentiam transumere, non secundum ipsius potentiam, sed secundum participantis impotentiam diffugere putantis speciem divinam illustrationis.
IV, p. 111. Praeparata autem esse oportet omnia ad gratiam divini fulgoris excipiendam.

XXXI, p. 299. Quid ergo in rebus aliis bonum? Huius, inquam, pro captu cuiusque imago. Omnia sequentia lumina primi luminis imagines sunt, a primo lumine dependentes.

See also: Ideo corpora in quibus terrea conditio praevalet, tanquam ineptissima luci, lumen nullum intus accipiunt. Non quia sit impotens lumen ad penetrandum. (De sole, ch. 9). 
1) One pinpoints here: a) the idea that the divine light stems from a caring, ontologically superior, principle spreading itself top-down, in order to illuminate what stands in a lower level of reality and is in need of illumination. In order to Christianize this picture, Ficino intentionally complicates this procedure by arguing not just for the divine light, but for its grace, through which he underlines the 'personal' commitment of the higher principle to the salvation of the lower levels of reality, b) the responsibility of the ontologically inferior beings to be light-friendly and vigilant, that is, to develop a certain readiness and prepare themselves for its reception. As for the latter, it depends on a robust sense of potency, while an equally uncompromising disapproval of impotence is advocated in both texts.

2) The relation between the higher level, wherein God and the divine light are to be situated, and the various lower ones, is depicted by Proclus in terms of participation, while Ficino resorts rather to the notions of imago and dependence; what is needed is the highest possible light receptivity, which varies pro captu of each being to attain the image of the Good. However different metaphors they may use, both Proclus and Ficino make the case for a transformation ad optimum.

3) The verbs subsisto and excipio bear a remarkable expressive potential. The first emphatically brings out how deteriora experience the gripping influence of the presence of gods, while the second underlines the challenge confronted by the recipient when receiving the divine light. Both of them can be taken to depict a certain backward movement, a subtle retreat. In the first case, this movement underlines the 'ethical distance' or the gap separating deteriora from gods. In the second case, it serves to bridge the gap and is made only to facilitate the light's reception; the recipient, 'aware', as it were, of the ontological superiority of what is going to be provided with, subtly retreats in order to fully embrace the gift coming from above.

4) One should not overlook here a crucial difference between Dodd's and Moerbeke's text. The former's accusative doxov̂v (line 18) has as its subject the $\alpha \lambda_{0} \tau$ (line 15), while the latter's genitive putantis (line 9) the participantis (line 8). At first sight, this divergence does not touch upon the light reception procedure, since regardless of whether the $\alpha \dot{\lambda} \lambda_{0} \tau \iota$ or the participans (if we follow Moerbeke's choice) has the appearance of "revolting against the divine form of illumination", as Dodds translates, the result remains the same: the divine light does not "assume dominion". These alternatives, however, do result in a radically different philosophical picture. If it is this $\alpha \lambda_{0} \tau \imath$ that has the appearance of "revolting against the divine form of illumination", then the emphasis is put 
rather on the obstacles and the external enemies confronted by the participant; what is underlined in this case is that a certain seemingly powerful being or entity, an anonymous factor, impedes the divine light's downward movement, while in reality the problem lies in the recipient's incompetence and overall ontological disablement. If, on the other hand, it is the participant that has the appearance of "revolting against the divine form of illumination", as Moerbeke's translation indicates, then the overall impression bears certain quasi-religious and sin-related connotations in that the resistance to the divine light implies that the recipient of the divine gift forcefully rejects it. Our attention is thus turned from its deficiency to a certain sense of distorted conversion, since the participant turns towards its cause not in order to thankfully embrace it, but aiming only to reject it. In this case, therefore, the participant is described not only as predominantly responsible for its overall condition, but is also charged for light-resistance and an 'intentional' ontological stagnation.

v)

26. (...) At vero ipsum unum immobiliter substituit. Si enim per motum, motus in ipso esset et motum neque unum adhuc erit, transmutatum ex eo quod unum. Aut si post ipsum sit motus, et ex uno erit et aut in infinitum aut immobiliter producet ipsum unum. (...)

\section{7 (...) Manet enim quale est, et quod} producitur aliud penes ipsum est. Inalteratum ergo generans consistit et inminoratum, fecunda potentia se ipsum multiplicans et a se ipso secundas ypostases exhibens.
XXX, p. 293. Primum sic ostenditur [sufficiens], quod scilicet immobile permanens creat. Nam si per motum, aut motus ille in eo est, aut extra. Si in eo, ipsum mutatum esset ab uno et bono, ergo quodammodo ab uno et bono discederet, debilitaretur igitur. Maxime vero potens apparet aliquid, cum aliud efficit (...) Sin extra sit, ergo motus ab eo productus utrum per motum an sine motu? Si primum, in infinitum ibitur. Si secundum, constat quod manens immobilis generat. Immo vero cum omnis motus impetus sit ad aliquid quod deest, deest aliquid primo si movetur. (...) Quare cum nulla sui transmutatione producat, stans in se ipso creat. Non ergo defectu proprio extrinsecus aliquid quaerens ad agendum exit, [p. 295] sed exuberante foecunditate se propagat. 
The terminological and philosophical continuity between the Elements of Theology and the Commentary on the Philebus is again easily identifiable. Ficino's philosophical intention is to show that the deployment of God's creative potential does not require any kind of movement. Since the adjective sufficiens comes from Plato's Philebus (ixavòv in 2od), where it is attributed to the good within a radically different context, Proclus is probably the pagan mediator and authority that facilitates this (unacknowledged) transition. Also, it is noteworthy that Ficino's scope is, as usually, much more restricted than that of Proclus. The former argues for certain 'features' of one specific entity, that is, the Christian God, while the latter aims for universality, for the relevant propositions start with omnis causa productiva and omne producens respectively.

\section{4 Conclusion}

Dedicated to the relation between the Elements of Theology and the Commentary on the Philebus, this short essay suggested some similarities and parallel motifs between these texts. The above annexes suffice to prove Ficino's peculiar creativity; they indicate that he does not simply reproduce ideas and texts, but takes pains to substantially rephrase (and even contradict) his sources or, when borrowing a whole proposition or a lengthy passage, to reorder the structure of the argument. They also bring out the fact that almost all of the crucial concepts grounding the Commentary on the Philebus are expounded in Proclian terms. What is most important, however, is to acknowledge how skillfully he exploits the potential of pagan arguments in order to promote Christian insights and ponder over Ficino's reasons for resorting so systematically to Proclus. Part of the answer may reside in his understanding that Proclus' writing, with all its impressive sense of impersonal authority and irrefutability resulting from its geometric model of presentation, accorded his Commentary on the Philebus the majestic and persuasive tone that was indispensable for his philosophical endeavor. In grounding the whole commentary on Proclus' axiomatic formulations (and not so much as one might expect on Dionysius' attractive, but suspicion-arousing, eloquence), Ficino provided his audience with a seemingly unquestionable and solid system of thought that, despite its pagan character, could easily be presented as the basis of a Christian worldview. 


\section{Bibliography}

\section{Primary Sources}

Damascius, Commentaire sur le Philèbe de Platon. Texte établi et traduit par Gerd Van Riel, Paris, Les Belles Lettres, 2008.

Marsilio Ficino, The Philebus Commentary. Introduction, critical edition and translation by Michael J.B. Allen, Tempe, Arizona, Arizona Center for Medieval and Renaissance Studies, 2000.

Plato, Philebus, introduction and translation by Dorothea Frede, Indianapolis/Cambridge, Hackett Publishing Company, 1993.

Proclus, Elementatio theologica, translata a Guillelmo de Morbecca, edition by Helmut Boese, Leuven, Leuven University Press, 1987.

\section{Secondary Sources}

Delcomminette, S. (2006), Le Philèbe de Platon. Introduction à l'agathologie platonicienne. Leiden/Boston, Brill.

Hankins, J. (1990), Plato in the Italian Renaissance. Vol. 1. New York/Leiden/Köln/ Copenhagen, Brill.

Robichaud, D. (2016), “Fragments of Marsilio Ficino's Translations and Use of Proclus' Elements of Theology and Elements of Physics: Evidence and Study" in Vivarium 54, p. 46-107.

Robichaud, D. (2018), Plato's Persona: Marsilio Ficino, Renaissance Humanism, and Platonic Traditions. Philadelphia, University of Pennsylvania Press.

Steel, C. (2013), "Ficino and Proclus: Arguments for the Platonic Doctrine of the Ideas" in J. Hankins, F. Meroi (eds), The Rebirth of Platonic Theology. Proceedings of a conference held at The Harvard University Center for Italian Renaissance Studies (Villa I Tatti) and the Istituto Nazionale di Studi sul Rinascimento (Florence, 26-27 April 2007) for Michael J.B. Allen, Florence, Leo S. Olschki Editore, p. 63-118.

Van Riel, G. (1997), "The Transcendent Cause: Iamblichus and the Philebus of Plato." in Syllecta Classica 8, p. 31-46.

Van Riel, G. (200o), Pleasure and the Good Life. Plato, Aristotle and the Neoplatonists. Leiden/Boston/Köln, Brill. 